Available online at : http://journal.unj.ac.id/unj/index.php/gjik

Gladi : Jurnal Ilmu Keolahragaan 12 (03) Spescial Issue 2021, 1-9

Permalink/DOI: https://doi.org/10.21009/GJIK.123.01

\title{
THE EFFECT OF JIGSAW COOPERATIVE LEARNING MODEL AIDED WITH INTERACTIVE MULTIMEDIA UPON LEARNING OUTCOME OF ON-GUARD POSITION ON PENCAK SILAT COURSE
}

\author{
I Ketut Sudiana ${ }^{1}$, I Gede Suwiwa ${ }^{1}$ \\ ${ }^{1}$ Department of Sport science, Ganesha University of Education \\ Singaraja, Indonesia \\ Correspondiing author. Email : ketut.sudiana@undiksha.ac.id
}

\begin{abstract}
Abstrak This study aimed at analyzing the effect of Jigsaw Cooperative Learning Model aided with interactive multimedia upon learning outcome of on-guard position on the theory and practice of Pencak Silat course. This is a pre-experimental study using one group pretest-posttest design. This study was conducted Sport Hall of Sport and Health Faculty in Jinengdalem Campus. The amount of the sample was 25 students. The variables consisted of independent variable that was the jigsaw cooperative learning model aided with interactive multimedia and the dependent variable was the learning outcome. The data collection technique was performance test of the basic on-guard position of Pencak Silat. Data were analyzed by using nonparametric inferential statistic in form of Wilcoxon Sign Rank Test which was used to analyse the differences of pre-test and post-test scores. The research finding showed that there were significant differences of on-guard position learning outcome on the course theory and practice of Pencak Silat course before and after the implementation of jigsaw cooperative learning model aided with interactive multimedia $(Z=4.378 ; p=0.000)$. Based on the result of Wilcoxon Sign Rank Test/Wilcoxon Match Pair Test, it was found that there was difference of on-guard position on Pencak Silat course before and after the implementation of Jigsaw cooperative learning model assisted with interactive multimedia. The after implementation/posttest mean score was (96.86) higher than before implementation/pre-test mean score (43.93) of Jigsaw cooperative learning model assisted with interactive multimedia.
\end{abstract}

Keywords: cooperative jigsaw, interactive multimedia, and attitudes pairs. 


\section{INTRODUCTION}

The demand of development based on students' dignity as an individual, as well as the development of science and technology, has created a new discipline and primarily known as didactic and method to be an instructional technology. Instructional technology is defined as theory and practice of designing, developing, using, managing, and evaluating the process and source of learning.

Vast development of science and technology as well as social development requires lecturers to keep up the new development and demand based on their expertise. Therefore, the lecturers' tasks are getting complex and challenging which trigger them to improve their individual and group capacity. There are so many fundamental and enormous changes happen in $21^{\text {st }}$ Century. Today we live in reformation era. In this era, information and communication technology has made fast information exchange to be unlimited by time and space.

The effort of developing instructional design is very important to be done by a lecturer. The essence of instructional design is designing a set of action aiming at changing the existing situation to be the desired situation. Therefore, it is obviously clear that the function of instructional design is an essential function because the instructional management and evaluation is basically depending on the instructional design made by the lecturer.

Any instructional activities should be systematically designed, as well as developing learning material, management of learning activities and evaluation, both for the process and result. In real, these efforts are performed by formulating operational competency, choosing and managing learning material to be consistent with the competency.

In the curriculum of Department of Physical, Health and Recreation Education, Faculty of Sport and Health, Ganesha University of Education, there is theory and practice of Pencak Silat course. It is designed for $3^{\text {rd }}$ semester students in Department of Physical, Health and Recreation Education with 2 credits. Mastering theory and practice of Pencak Silat course is important. It is because the output of this department will be a teacher at school. At school especially in subject of physical, sport and health, Pencak Silat is one of the materials that should be taught. Considering the importance of theory and practice of Pencak Silat to be mastered by the students, so the lecturer should create conducive learning condition and situation in order to achieve the goal of this course effectively and efficiently. The lecturer should not only teach by merely delivering knowledge, skill and attitude to the students. However, the lecturer should teach the students to learn in the context of how to seek, find, and master a knowledge, skill and attitude (Putrayasa, 2005: 2). By optimizing activities of movement, creativity, and role of the students, it is expected to develop students' potential and capacity learning, as well as potential of learning source in their surroundings.

By the vast development of information and communication media, both its hardware and software, there is a changing role of lecturer as well as the lecturer of this department in delivering message or information. Lecturer is no longer the only information source for students' learning activities.

Nowadays, the educators have got access to use many kinds of 
technology products to improve instructional effectiveness. One of the technology products is multimedia. Through multimedia, it can be shown real event related to the learning material so the learning will be more contextual and the students would be easier to understand.

However, there are still many lecturers who are not capable of combining innovative learning and multimedia assisted learning model. Whereas many studies have proven that instructional assisted with multimedia is more effective than other instructional models, because multimedia has many potentials that can be used to improve the effectiveness of instructional process. This condition affected the students' learning outcomes in Pencak Silat course, in which classically the three classes in total 98 students were categorized $26.5 \%$ of excellent, $58.2 \%$ good, $9.2 \%$ sufficient, $0 \%$ insufficient, and $6.1 \%$ poor. Actually, learning outcome of the theory and practice of Pencak Silat was classically fulfilling criteria of success, but students' success distribution could be possibly improved if the instructional condition was supported by sufficient strategy and media. The improvement of instructional quality which implies to the improvement of students' learning outcome needs many efforts. These efforts are related to many components involved in the instruction, one of them is by combining innovative learning model and the use of instructional media.

Jigsaw cooperative learning model is an instructional model which is able to attract students to actively and creatively think in the instructional process. This model is not only developing intellectual ability but also the entire existing potentials, including emotional and skill development. By implementing this model, the students will be trained to be braver in proposing their ideas, to be more cooperative, individual development, and individual responsible, positively interdependent both in individual interaction and group process. The use of this instructional model effectively and efficiently will decrease lecturer's monopoly in the learning process and students' boredom in learning the material (lie, 2010:18).

According to some education researchers, Talebi and Sobhani (2012) proposed that performance of experimental group on interview (posttest) which was conducted in the end of course showed the mean score of this group significantly higher than control group. Therefore, cooperative leaning approach was effectively implemented to improve students' language competence. Other study proved that qualitative data showed students in cooperative learning group found bigger benefits than the traditional group. This study will benefit the instructor and students in long distance learning to improve practice teaching learning in virtual class (Kupczynski, L., Mundy, M. A., Goswami, J. \& Meling, V. 2012).

Considering the importance of innovation in the instruction to improve learning outcome, so the researcher interested in conducting research: The Effect of Jigsaw Cooperative Learning Model Aided with Interactive Multimedia upon Learning Outcome of On-Guard Position on Pencak Silat Course (on students of Department of Physical, Health and Recreation Education, Faculty of Sport and Health, Ganesha University of Education).

Based on the above research background, the research problem that would be reviewed was: "Is there any learning outcome differences of onguard position on Pencak Silat course 
before and after the implementation of Jigsaw cooperative learning model assisted with interactive multimedia?"

In line with the research problem, the hypothesis of this study was: "There is learning outcome differences of on-guard position on Pencak Silat course before and after the implementation of Jigsaw cooperative learning model assisted with interactive multimedia".

\section{METHODS}

This is a pre-experimental research with one group pretest-posttest design (Sugiyono, 2013). There was one group as subject in this research. Firstly, there was evaluation and then treatment in an arrange of time, and finally evaluation again for the second time. The research design can be seen in the following Picture 01.

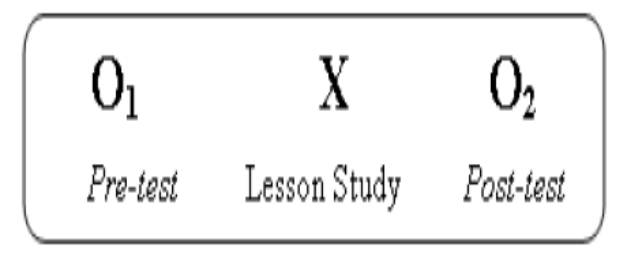

Figure 1. Research Design of One Group Pretest-Posttest Design

One group pretest-posttest design was chosen the effectiveness or effect of the treatment upon dependent variable (Sugiyono, 2013). In this research one group subject was treated by jigsaw cooperative learning model assisted with interactive multimedia. Students' learning outcome was evaluated in this subject. Students' learning outcome was done before the implementation of jigsaw cooperative learning model assisted with interactive multimedia which was marked by $\mathrm{O} 1$ (Pre-test), and there was evaluation after the treatment which was marked as $\mathrm{O} 2$ (Post-test). The difference of these two evaluations was considered as the effect of the implemented jigsaw cooperative learning model assisted with interactive multimedia. Since the research subject was not too many and considering the above phenomenon, so this research used census sampling which was all of the population became the research sample consisted of 25 students. Test was used as the data collection technique. The data were in form of learning outcome of Pencak Silat onguard position. The research instrument had been tested before it was used in this research. All items of the instruments were valid and reliable. Students' learning outcome was analyzed by using inferential and descriptive statistical analysis, in which hypothetical test used Wilcoxon signedrank test/Wilcoxon pair test (Agusyana, 2011, and Candiasa, 2010).

\section{RESULTS}

\section{Research finding}

Descriptive statistical analysis technique for students' learning outcome used percentage, mean score, median, modus, standard deviation, variance, range, minimum score, maximum score, and percentile from score before (pretest) and after (posttest) the implementation of jigsaw cooperative learning model assisted with interactive multimedia. The descriptive analysis result is stated in Table 1.

Table 1.

Descriptive Analysis Result 
Gladi Jurnal Ilmu Keolahragaan, 12 (03), July- 5

I Ketut Sudiana, I Gede Suwiwa

\begin{tabular}{lll}
\hline & Pre-test & Post-test \\
\hline $\mathrm{N} \quad$ Valid & 25 & 25 \\
\hline \multicolumn{1}{c}{ Gone } & 0 & 0 \\
\hline Mean Score & 43,93 & 96,86 \\
\hline Median & 44,10 & 96,70 \\
\hline Modus & 44,10 & 99,20 \\
\hline Standard deviation & 2,66 & 2,06 \\
\hline Variance & 7,07 & 4,25 \\
\hline Range & 10,90 & 6,70 \\
\hline Minimum & 39,10 & 92,50 \\
\hline Maximum & 50,00 & 99,20 \\
\hline Total & 1098,20 & 2421,40 \\
\hline
\end{tabular}

\section{Discussion}

Cooperative learning is under paradigm of constructivist theory which views the students would be easier to find and comprehend a difficult concept if they discuss with their friends. So, social nature and the use of partner group becomes main aspect in cooperative learning. Cooperative process may create effective teaching learning process with two ways communication between the lecturer and students which not only emphasizing on what has been learnt but how the students should learn. Social constructivism was developed by Lev Semenovich Vygotsky, who stated that knowledge formation and cognitive development are formed through internalization/social process mastery (Sani, 2013). Based on this theory, knowledge exists in human mind and a human interpretation upon their experience about world, perspective, conventional, tentative, and evolutionary. New knowledge/concept is built through times in social context. Students interact with knowledge material and integrate old information with new information and awareness of the subject being learnt (metacognitive). Principles of this theory are: (1) social learning: students learn through interaction with more capable adults or friends; (2) closest development zone: students are easier to learn concept if the concept is on their closest development zone; (3) cognitive internship: students gradually master skill through interaction with other people who have mastered the skills; (4) Scaffolding; students are given complex, difficult, and realistic tasks which is further given a sufficient help to finish these tasks. One of learning types that is possible to accommodate the learning of constructivism theory 
and cooperative learning is Jigsaw cooperative learning model.

In jigsaw model, the class is divided into several teams consisting of 5 or 6 students with heterogeneous characteristic. Even the academic was presented into the students in form of text; and every student is responsible to study a part of the academic material. Every member in all different teams has responsibility to study the same part and further grouping to help each other in reviewing the same part. Such students group is called "expert group". Then, the students in expert group back to their own home team to teach other member about the material being leant in the expert group. After meeting and discussion in home teams, all of the students were evaluated individually about the learning material being learnt (Waluyo, 2006:16).

Steps of Jigsaw cooperative learning model: (1) lecturer socializes to the students about Jigsaw cooperative learning model which would be used as instructional setting; (2) lecturer and students agree to form home teams; (3) lecturer and students in all home teams agree to share expert group and giving tasks to each expert; (4) lecturer and students agree the time limitation of discussion in expert group and time used for tutoring their friends in home teams; (5) expert group is allowed to work within their group to discuss their responsible tasks as long as the time given; (6) after expert group finishing their task, each expert back to their home teams; (7) in the home team, each expert explain what they have learnt to the other expert respectively, other expert elaborate the other expert's explanation in order to complete the whole task, in this case the lecturer should observe and guide the students in order to create effective tutorial within the teams; (8) lecturer point randomly one of the teams to present their discussion, other teams observing, responding, questioning, explaining, and refining other teams report, lecturer collects team report to be corrected, scored and returned to the students in the next meeting, as well as announcing teams score, and giving reward to the best team (Santyasa and Sukadi, 2007:42).

Discussion of this research is focused on hypothetical test result. The discussion cannot be separated from descriptive analysis result and statistical analysis consisting of independent variable: learning model and dependent variable: students' learning outcome.

Based on the result of Wilcoxon Sign Rank Test/Wilcoxon Match Pair Test, it was found that there was difference of on-guard position on Pencak Silat course before and after the implementation of Jigsaw cooperative learning model assisted with interactive multimedia. The after implementation/posttest mean score was (96.86) higher than before implementation/pre-test mean score (43.93) of Jigsaw cooperative learning model assisted with interactive multimedia.

This result is consistent with research conducted by Mustamiin (2013) who stated that there is different learning outcome of Social Science subject between students who were treated by using Jigsaw cooperative learning model and students who were treated by conventional teaching model. Research finding from Wacika (2013) also revealed that there was difference of students learning achievement in Social Science subject between students who were treated by using Jigsaw cooperative learning model and students who were treated by conventional teaching model. Besides that, Mujenah (2013) stated that there was effect of 
jigsaw cooperative learning upon students' achievement in Civic subject. Talebi, F. and Sobhani, A. (2012) reported group experimental performance on oral interview (posttest) conducted in the end of the course showed mean score of this group was significantly higher than control group. Learning through jigsaw cooperative learning model could combine other students' opinion and rearranging those opinions to get the best opinion. This finding is supported by Cooper (in Wina, 2006) who stated that students who are actively involved in group work will be using their time more to synthetize and integrate the concepts rather than only listening the lecturing. In group discussion, students are facing other ideas which are in line with their idea. It will trigger students' selfconfident. Students will also face other ideas conflicting to their idea. This condition will force them to reconstruct their ideas. Interaction in cooperative learning will motivate the students and trigger their thinking ability, and finally considering education as long term process and not a short term exercises.

Jigsaw cooperative learning model places students as part of a cooperative system in achieving optimum result in learning. It is possibly implemented to the students in physical education so they could study structurally and systematically through small group working together for the same purpose. While working together with other students within the small group, they also learn other collaborative and social skills. Learning activities are done in group activity, so every student is teaching each other through exchanging minds, experiences, or ideas.

Interactive media really helps the students to visualize the right onguard position movement in Pencak
Silat learning material. Besides that, in Jigsaw cooperative learning every group member will help each other and highly motivated to reach group success. Therefore, every individual will have the same opportunity to contribute for the group success (Trianto, 2007).

Consistency the finding of this research with previous researches strengthen the hypothesis proof of this research empirically. That was a significant learning outcome differences of on-guard position on Pencak Silat course before and after the implementation of Jigsaw cooperative learning model assisted with interactive multimedia.

Based on the above conclusion, it can be implied that: (1) lecturer should be aware that Jigsaw cooperative learning model gives more opportunity to the students to build their own knowledge, find information, manage information, socially interact, deliver information and interactive learning could ease learning process; (2) this research finding demands the students to use many kinds of information source, not only learning material from textbook but also other supporting books and learning source both in printed and electronic form. Therefore, students will be more enthusiastic to dig and manage information deeply; and (3) in university level, this finding has an implication that university should be a reflection of bigger community, and the class should be designed as a place to solve problem together and a place to learn responsibility as well as students' social development through jigsaw cooperative learning setting.

\section{CONCLUSIONS}

Based on the result of data analysis and discussion it can be concluded that there was significant 
difference of on-guard position on Pencak Silat course before and after the implementation of Jigsaw cooperative learning model assisted with interactive multimedia $(\mathrm{Z}=4.378 ; \mathrm{p}=0.000)$.

Based on the conclusion, so the researcher proposes some suggestions to other parties such as: (1) to other researcher, there should be further study about Jigsaw cooperative learning model assisted with interactive multimedia. In this case not only in students learning outcome on Pencak Silat course but also in other assessment and could be implemented for other subjects. Besides that, the research samples should be bigger and within broader area, in more various classes, so the finding of this research will have more review as comparison. Therefore, the precision of Jigsaw cooperative learning model implementation can be optimized; and (2) to the Institution of Educator and Education Sources, Jigsaw cooperative learning model assisted with interactive multimedia should be socialized to other Physical Education Department lecturers especially for Pencak Silat course. It is intended in order the Jigsaw cooperative learning model assisted with interactive multimedia implementation can be developed in Pencak Silat course optimally, by reviewing the obstacles, weaknesses, strengths, in any situations and conditions in the field.

\section{REFERENCES}

Agusyana, Y. 2009. Olah Data Skripsi dan Penelitian dengan SPSS 19. Jakarta: PT. Gramedia

Candiasa, I M. 2010. Statistik Univariat dan Bivariat Disertai Aplikasi SPSS. Singaraja: Unit Penerbitan UNDIKSHA.

Kupczynski, L., Mundy, M. A., Goswami, J. \& Meling, V. 2012.
Cooperatif learning in distance learning: A mixed methods study. International Journal of Instruksi. 5. (2). 81-90. Tersedia pada: http://www.eiji.net/dosyalar/iji_2012_2_5.pdf - Diakses pada tanggal: 7 Oktober 2012

Lie A. 2002. Cooperative learning. Jakarta: Grasindo.

Mayer, R. E. 2007. Multimedia learning. USA: Cambridge University Press.

Mujenah. 2013. Pengaruh Model Kooperatif Tipe Jigsaw Dan Sikap Sosial Terhadap Hasil Belajar Siswa Pada Mata Pelajaran Pkn Kelas VIII MTSN Model Selong Kabupaten Lombok Timur Tahun Pelajaran 2012/2013. Singaraja: Prodi Pendas PPS UNDIKSHA

Mustamiin, M.Z. 2013. Pengaruh Penggunaan Model Kooperatif Learning Tipe Jigsaw Terhadap Hasil Belajar Ips Di Tinjau Dari Motivasi Berpretasi. Tesis (tidak diterbitkan). Singaraja: Prodi Pendas PPS UNDIKSHA

Putrayasa, Ida Bagus. 2005.

Pembelajaran Bahasa Indonesia Berbasis Inkuiri dalam Upaya Meningkatkan Aktivitas, Kreativitas, dan Logikalitas. Orasi Pengenalan Jabatan Guru Besar Tetap dalam Bidang Bahasa pada Fakultas Pendidikan Bahasa dan Seni IKIP Negeri Sinagaraja, Disampaikan pada sidang terbuka Senat IKIP Negeri Singaraja, Rabu, 23 Maret 2005

Sani, R. A. 2013. Inovasi Pembelajaran. Jakarta: PT. Bumi Aksara

Santyasa, I Wayan dan Sukadi. 2007. model- model Pembelajaran Inovatif. Makalah Disajikan dalam Pelatihan Sertifikasi Guru 
Gladi Jurnal Ilmu Keolahragaan, 12 (03), July- 9

I Ketut Sudiana, I Gede Suwiwa

bagi Para Guru SD dan SMP di

Provinsi Bali. Universitas

Pendidikan Ganesha. Singaraja

tanggal 26-30 Desember 2007. 